\title{
A multi-product pricing and inventory model with production rate proportional to power demand rate
}

\author{
Keshavarzfard, R. ${ }^{a}$, Makui, A. ${ }^{\mathrm{b}}$, Tavakkoli-Moghaddam, R. ${ }^{\mathrm{c}, \mathrm{d},{ }^{*}}$ \\ ${ }^{a}$ School of Industrial Engineering, South Tehran Branch, Islamic Azad University, Tehran, Iran \\ ${ }^{b}$ School of Industrial Engineering, Iran University of Science and Technology, Tehran, Iran \\ 'School of Industrial Engineering, College of Engineering, University of Tehran, Tehran, Iran \\ ${ }^{d}$ Arts et Métiers ParisTech, LCFC, Metz, France
}

\begin{abstract}
A B S T R A C T
This paper deals with an economic lot size model when demand follows a power law and changes with time, owing to the fact that this kind of pattern is suitable for so many real situations. Production rate is presumed to be proportional to demand rate. Also since that demand is price sensitive in reality, we suppose that demand decreases linearly with price. With regard to these points, in this article a joint pricing and inventory model is presented where demand depends on time with a power pattern and price linearly, production rate changes pro rata with demand rate and multiple items are considered. The principal consideration of the study is to satisfy the demand and optimize the profit for all items in the system, simultaneously. Setup, holding, backlogging and production costs are involved in the inventory system. The aim is to maximize total profit function and achieve optimum values of scheduling period, reorder point and price. Employing mathematical modelling and optimization methods, the existence of the optimal solutions is proved, and then a simple heuristic algorithm is presented to maximize total inventory profit and determine the best values of variables. A numerical analysis is carried out to illustrate the applications of the proposed models.
\end{abstract}

\section{ARTICLE INFO}

Keywords:

Pricing model;

Inventory model;

Economic production quantity

(EPQ);

Backordered shortages;

Power demand pattern

*Corresponding author:

tavakoli@ut.ac.ir

(Tavakkoli-Moghaddam, R.)

Article history:

Received 14 August 2017

Revised 15 February 2019

Accepted 24 February 2019

\section{References}

[1] Taft, E.W. (1918). The most economical production lot, The Iron Age, Vol. 101, 1410-1412.

[2] Barbosa, L.C., Friedman, M. (1978). Deterministic inventory lot size models - A general root law, Management Science, Vol. 24, No. 8, 819-826, doi: 10.1287/mnsc.24.8.819.

[3] Mitra, A., Cox, J.F., Jesse Jr, R.R. (1984). A note on determining order quantities with a linear trend in demand, The Journal of the Operational Research Society, Vol. 35, No. 2, 141-144, doi: 10.2307/2581442.

[4] Sakaguchi, M. (2009). Inventory model for an inventory system with time-varying demand rate, International Journal of Production Economics, Vol. 122, No. 1, 269-275, doi: 10.1016/j.ijpe.2009.06.003.

[5] Khanra, S., Mandal, B., Sarkar, B. (2013). An inventory model with time dependent demand and shortages under trade credit policy, Economic Modelling, Vol. 35, 349-355, doi: 10.1016/i.econmod.2013.07.031.

[6] Sarkar, B., Mandal, P., Sarkar, S. (2014). An EMQ model with price and time dependent demand under the effect of reliability and inflation, Applied Mathematics and Computation, Vol. 231, 414-421, doi: 10.1016/j.amc.2014. $\underline{01.004}$.

[7] Escuín, D., Polo, L., Ciprés, D. (2017). On the comparison of inventory replenishment policies with time-varying stochastic demand for the paper industry, Journal of Computational and Applied Mathematics, Vol. 309, 424-434, doi: 10.1016/j.cam.2016.03.027.

[8] Naddor, E. (1966). Inventory Systems, John Wiley and Sons, New York, USA.

[9] Lee, W.-C., Wu, J.-W. (2002). An EOQ model for items with Weibull distributed deterioration, shortages and power demand pattern, International Journal of Information and Management Sciences, Vol. 13, No. 2, 19-34. 
[10] Singh, T.J., Singh, S.R., Dutt, R. (2009). An EOQ model for perishable items with power demand and partial backlogging, International Journal of Production Economics, Vol. 15, No. 1, 65-72.

[11] Sicilia, J., Febles-Acosta, J., González-De La Rosa, M. (2012). Deterministic inventory systems with power demand pattern, Asia-Pacific Journal of Operational Research, Vol. 29, No. 05, Art. No. 1250025, doi: 10.1142/S02175 9591250025X.

[12] Rajeswari, N., Vanjikkodi, T. (2012). An inventory model for items with two parameter Weibull distribution deterioration and backlogging, American Journal of Operations Research, Vol. 2, No. 2, 247-252, doi: 10.4236/ ajor.2012.22029.

[13] Mishra, S.S., Singh, P.K. (2013). Partial backlogging EOQ model for queued customers with power demand and quadratic deterioration: computational approach, American Journal of Operational Research, Vol. 3, No. 2, 13-27.

[14] Sicilia, J., González-De-la-Rosa, M., Febles-Acosta, J., Alcaide-López-de-Pablo, D. (2014). An inventory model for deteriorating items with shortages and time-varying demand, International Journal of Production Economics, Vol. 155, 155-162, doi: 10.1016/j.ijpe.2014.01.024.

[15] Sicilia, J., González-De-la-Rosa, M., Febles-Acosta, J., Alcaide-López-de-Pablo, D. (2014). Optimal policy for an inventory system with power demand, backlogged shortages and production rate proportional to demand rate, International Journal of Production Economics, Vol. 155, 163-171, doi: 10.1016/i.ijpe.2013.11.020.

[16] Sicilia, J., González-De-la-Rosa, M., Febles-Acosta, J., Alcaide-López-de-Pablo, D. (2015). Optimal inventory policies for uniform replenishment systems with time-dependent demand, International Journal of Production Research, Vol. 53, No. 12, 3603-3622, doi: 10.1080/00207543.2014.983618.

[17] San-José, L.A., Sicilia, J., González-De-la-Rosa, M., Febles-Acosta, J. (2017). Optimal inventory policy under power demand pattern and partial backlogging, Applied Mathematical Modelling, Vol. 46, 618-630, doi: 10.1016/j.apm. 2017.01.082.

[18] Tripathi, R.P., Pareek, S., Kaur, M. (2017). Inventory models with power demand and inventory-induced demand with holding cost functions, American Journal of Applied Sciences, Vol. 14, No. 6, 607-613, doi: 10.3844/ajassp. 2017.607.613.

[19] Lau, H.-S., Lau, A.H.-L., Kottas, J.F. (2001). Pricing/inventory decisions and profit shares in a non-integrated marketing channel for a single-period product, Journal of the Operational Research Society, Vol. 52, No. 6, 682690, doi: 10.1057/palgrave.jors.2601131.

[20] Yang, C.-T., Ouyang, L.-Y., Wu, H.-H. (2009). Retailer's optimal pricing and ordering policies for noninstantaneous deteriorating items with price-dependent demand and partial backlogging, Mathematical Problems in Engineering, Vol. 2009, Article ID 198305, doi: 10.1155/2009/198305.

[21] Banerjee, S., Sharma, A. (2010). Optimal procurement and pricing policies for inventory models with price and time dependent seasonal demand, Mathematical and Computer Modelling, Vol. 51, No. 5-6, 700-714, doi: 10.1016 Lj.mcm.2009.10.022.

[22] Soon, W. (2011). A review of multi-product pricing models, Applied Mathematics and Computation, Vol. 217, No. 21, 8149-8165, doi: 10.1016/i.amc.2011.03.042.

[23] Maihami, R., Kamalabadi, I.N. (2012). Joint pricing and inventory control for non-instantaneous deteriorating items with partial backlogging and time and price dependent demand, International Journal of Production Economics, Vol. 136, No. 1, 116-122, doi: 10.1016/j.ijpe.2011.09.020.

[24] Shavandi, H., Mahlooji, H., Nosratian, N.E. (2012). A constrained multi-product pricing and inventory control problem, Applied Soft Computing, Vol. 12, No. 8, 2454-2461, doi: 10.1016/j.asoc.2012.03.036.

[25] Pal, B., Sana, S.S., Chaudhuri, K. (2012). Multi-item EOQ model while demand is sales price and price break sensitive, Economic Modelling, Vol. 29, No. 6, 2283-2288, doi: 10.1016/i.econmod.2012.06.039.

[26] Zhu, S.X. (2013). Dynamic replenishment, production, and pricing decisions, in the face of supply disruption and random price-sensitive demand, International Journal of Production Economics, Vol. 146, No. 2, 612-619, doi: 10.1016/j.ijpe.2013.08.009.

[27] Qin, Y., Wang, J., Wei, C. (2014). Joint pricing and inventory control for fresh produce and foods with quality and physical quantity deteriorating simultaneously, International Journal of Production Economics, Vol. 152, 42-48, doi: 10.1016/j.ijpe.2014.01.005.

[28] Liu, G., Zhang, J., Tang, W. (2015). Joint dynamic pricing and investment strategy for perishable foods with pricequality dependent demand, Annals of Operations Research, Vol. 226, No. 1, 397-416, doi: 10.1007/s10479-0141671-x.

[29] Panda, S., Modak, N.M., Sana, S.S., Basu, M. (2015). Pricing and replenishment policies in dual-channel supply chain under continuous unit cost decrease, Applied Mathematics and Computation, Vol. 256, 913-929, doi: 10.1016/j.amc.2015.01.081.

[30] Alfares, H.K., Ghaithan, A.M. (2016). Inventory and pricing model with price-dependent demand, time-varying holding cost, and quantity discounts, Computers \& Industrial Engineering, Vol. 94, 170-177, doi: 10.1016/ j.cie.2016.02.009.

[31] Chiu, Y.-S.P., Kuo, J.-S., Chiu, S.W., Hsieh, Y.-T. (2016). Effect of delayed differentiation on a multiproduct vendorbuyer integrated inventory system with rework, Advances in Production Engineering \& Management, Vol. 11, No. 4, 333-344, doi: 10.14743/apem2016.4.231.

[32] Gholamian, M.R., Heydari, M. (2017). An inventory model with METRIC approach in location-routing-inventory problem, Advances in Production Engineering \& Management, Vol. 12, No. 2, 115-126, doi: 10.14743/apem2017. $\underline{2.244}$.

[33] Stoer, J., Bulirsch, R. (2013). Introduction to numerical analysis, Springer Science \& Business Media, New York, USA. 


\section{APEM}

\title{
Model oblikovanja cen in zalog z več izdelki s stopnjo proizvodnje, sorazmerno z eksponentno stopnjo povpraševanja
}

\author{
Keshavarzfard, R. ${ }^{a}$, Makui, A. ${ }^{b}$, Tavakkoli-Moghaddam, R. ${ }^{c, d,{ }^{*}}$ \\ ${ }^{a}$ School of Industrial Engineering, South Tehran Branch, Islamic Azad University, Tehran, Iran \\ ${ }^{\text {b} S c h o o l ~ o f ~ I n d u s t r i a l ~ E n g i n e e r i n g, ~ I r a n ~ U n i v e r s i t y ~ o f ~ S c i e n c e ~ a n d ~ T e c h n o l o g y, ~ T e h r a n, ~ I r a n ~}$ \\ 'School of Industrial Engineering, College of Engineering, University of Tehran, Tehran, Iran \\ ${ }^{d}$ Arts et Métiers ParisTech, LCFC, Metz, France
}

\section{POVZETEK}

Prispevek obravnava ekonomski model velikosti serije, pri katerem se povpraševanje eksponentno spreminja s časom, kar je značilen vzorec za mnogo resničnih situacij. Domneva se, da je stopnja proizvodnje sorazmerna s stopnjo povpraševanja. Ker je povpraševanje odvisno od cene, domnevamo, da se povpraševanje linearno zmanjšuje $s$ ceno. V zvezi s temi točkami je v prispevku predstavljen skupni model cen in zalog za več artiklov, pri katerem je povpraševanje eksponentno odvisno od časa, cena linearno, stopnja proizvodnje pa je sorazmerna s stopnjo povpraševanja. Glavna naloga študije je zadovoljiti povpraševanje in optimizirati dobiček za vse artikle v sistemu hkrati. Stroški postavitve, zadrževanja, zaostankov in stroškov proizvodnje so vključeni v sistem zalog. Cilj je maksimirati funkcijo skupnega dobička in doseči optimalne vrednosti obdobja načrtovanja, točke naročila in cene. $\mathrm{Z}$ uporabo metod matematičnega modeliranja in optimizacije se dokaže obstoj optimalnih rešitev, nato pa je predstavljen preprost hevristični algoritem, ki maksimira skupni dobiček in določi najboljše vrednosti spremenljivk. Za ponazoritev uporabe predlaganih modelov je izvedena številčna analiza.
\end{abstract}

\section{PODATKI O ČLANKU}

Ključne besede:

Model cen;

Model zalog;

Gospodarna količina proizvodnje

(EPQ);

Pomanjkanje ponaročil;

Eksponentno povpraševanje

* Kontaktna oseba:

tavakoli@ut.ac.ir

(Tavakkoli-Moghaddam, R.)

Zgodovina članka:

Prejet 14. avgusta 2017

Popravljen 15. februarja 2019

Sprejet 24. februarja 2019 